\title{
LARYNGOLOGY
}

\section{Relationship between socio-demographic characteristics and vocal fold nodules, polyps and oedema}

\author{
Relazione fra edema della laringe, noduli e polipi delle corde vocali \\ e caratteristiche socio-demografiche
}

\author{
J. MILOVANOVIC 1,2, M. VUKASINOVIC ${ }^{2}$, A. JOTIC ${ }^{1,2}$, H. VLAJINAC ${ }^{3}$, A. MILOVANOVIC ${ }^{1,4}$, B. PAVLOVIC ${ }^{1,2}$, \\ B. BANKO ${ }^{5}$, J. MAKSIMOVIC ${ }^{3}$
}

${ }^{1}$ Faculty of Medicine, University of Belgrade, Serbia; ${ }^{2}$ Clinic for Otorhinolaryngology and Maxillofacial Surgery, Clinical Centre of Serbia, Belgrade, Serbia; ${ }^{3}$ Institute of Epidemiology, Faculty of Medicine, University of Belgrade, Serbia; ${ }^{4}$ Clinic for Physical Medicine and Rehabilitation, Clinical Centre of Serbia, Belgrade, Serbia; ${ }^{5}$ Center for Radiology and Magnetic Resonance Imaging, Clinical Centre of Serbia, Belgrade, Serbia

\begin{abstract}
SUMMARY
The aim of our study was to compare socio-demographic characteristics of vocal fold nodules, polyps and oedema. The study included patients diagnosed for the first time with vocal fold nodules, polyps and oedema at the Communication Disorders Care Center of Clinic for Otorhinolaryngology and Maxillofacial Surgery in Clinical Center of Serbia, Belgrade. Diagnosis was made on the basis of symptoms, clinical otorhinolaryngological and phoniatric examination and endovideolaryngostroboscopic findings. A self-administered questionnaire was used to collect the following data: socio-demographic status, exposure to occupational noise and air pollution, occupational voice demands, health habits, symptoms of the present voice problems and voice problems in the family. By multivariate logistic regression analyses, nodules and oedema were more frequent in women than men in comparison with polyps $(\mathrm{p}<0.001)$. Patients with nodules and polyps were younger than those with oedema $(\mathrm{p}<0.001)$. Patients with nodules were more frequently lecturers, singers and actors compared with polyp patients $(\mathrm{p}=0.006)$, had occupational voice demands more frequently than patients with oedema $(p=0.037)$ and were less frequently smokers than patients with polyps $(p=0.043)$ and those with oedema ( $<<0.001)$. Patients with oedema were more frequently current smokers than patients with nodules and those with polyps $(p<0.001)$. Hoarseness as the main symptom was more frequent among patients with nodules than among patients with polyps $(p=0.040)$ and those with oedema $(p=0.001)$. Voice problems in the family was more frequently reported by oedema patients than by patients with polyps $(p=0.005)$. These findings are in agreement with majority of previous studies and may be of help in investigations on the aetiology of the disease.
\end{abstract}

KEY WORDS: Vocal fold nodules $\bullet$ Polyps $\bullet$ Edema $\bullet$ Epidemiological study

\section{RIASSUNTO}

Scopo del nostro studio è stato quello di paragonare le caratteristiche socio-demografiche dei pazienti con noduli, polipi ed edema delle corde vocali. Lo studio ha incluso pazienti con una prima diagnosi di noduli, polipi od edema delle corde vocali presso il Centro di Disordini della Comunicazione della Clinica Otorinolaringoiatrica e Maxillo Facciale di Belgrado, Serbia. La diagnosi è stata posta sulla base dei sintomi, della visita ORL e foniatrica con videolaringostroboscopia. È stato utilizzato un questionario per la raccolta dei seguenti dati: status socio-demografico, esposizione al rumore nell'ambiente lavorativo ed inquinamento dell'aria, utilizzo della voce nelle attività lavorative, abitudini di vita, sintomi riferibili alla disfonia attuale ed eventuali disfonici in famiglia. Un'analisi multivariata ha evidenziato come i noduli e l'edema siano più frequenti nelle donne rispetto agli uomini se paragonate ai polipi $(p<0,001)$. I pazienti con noduli sono risultati essere più giovani di quelli con edema $(p<0,001)$. Quelli con noduli erano più frequentemente conferenzieri, cantanti od attori se paragonati a quelli con i polipi $(p=0,006)$, avevano una storia di abuso vocale più frequentemente rispetto ai pazienti con edema $(p=0,037)$ ed erano meno frequentemente fumatori rispetto ai pazienti con polipi $(p=0,043)$ e a quelli con edema $(p<0,001)$. I pazienti con edema erano più frequentemente fumatori rispetto ai pazienti con noduli e polipi $(p<0,001)$. La faringodinia come sintomo principale era più frequente nei pazienti con noduli rispetto a quelli con i polipi $(p=0,040)$ o con edema ( $p=0,001)$. I problemi di voce in famiglia erano più frequentemente riportati fra i pazienti con edema rispetto a quelli con polipi $(p=0,005)$. Questi risultati sono in accordo con i principali studi pubblicati in letteratura e possono essere di aiuto nella ricerca dell'eziologia della patologia.

PAROLE CHIAVE: Noduli corde vocali $\bullet$ Polipi corde vocali $\bullet$ Edema corde vocali $\bullet$ Studio epidemiologico

Cite this article as: Acta Otorhinolaryngol Ital 2018;38:424-430. http://dx.doi.org/10.14639/0392-100X-1983

(C) Società Italiana di Otorinolaringologia e Chirurgia Cervico-Facciale 


\section{Introduction}

Vocal fold nodules, polyps and oedema are classified as vocal fold masses, also known as exudation lesions of Reinke space ${ }^{12}$. The aetiology, pathogenesis, histology and clinical aspects of these lesions are still rather controversial, as well as their management.

It has been considered that both genetic and environmental factors play a role in the development of vocal fold (VF) disease ${ }^{34}$. Gender, age, education level, occupations, vocal abuse or misuse, cigarette smoking, alcohol consumption, unfavourable microclimate conditions at work and comorbidities such as gastro-oesophageal reflux, infections, allergy and thyroid diseases are recongised risk factors ${ }^{5-13}$.

Investigations of factors related to VF nodules, polyps and oedema show some differences between these three forms of VF disease. For example, in the study by Nagata et al. ${ }^{5}$ polyps were frequent in middle-aged subjects of both sexes, whereas nodules were more common in boys and middle-aged women. Smoking was more frequently associated with VF oedema than with nodules and polyps ${ }^{7}$. These and similar findings raised the question of whether VF nodules, polyps and oedema were the same entity. Although only genetic studies and studies at molecular level might definitively answer the question, it is of help to understand the main differences among VF nodules, polyps and oedema in terms of socio-demographic characteristics.

The aim of our study was to compare the socio-demographic characteristics of vocal fold nodules, polyps and oedema.

\section{Materials and methods}

The study included patients diagnosed for the first time with VF nodules, polyps and oedema at the Communication Disorders Care Center of Clinic for Otorhinolaryngology and Maxillofacial Surgery in Clinical Center of Serbia, Belgrade, during October 2014 - March 2015.

Diagnosis was made on the basis of symptoms, clinical otorhinolaryngological and phoniatric examination and endovideolaryngostroboscopic findings. The diagnosis was established by multidisciplinary team consisted of two phoniatricians, two laryngologists and two logopaedics with at least 20 years of experience in the field of communication disorders. Endovideolaryngostroboscopy was a key tool because it allows all members of the team to take a part in examination at the same time. Inclusion criteria were age over 18 years and voluntary participation. Exclusion criteria were neurological and psychiatric illness, malignant disease, severe hearing loss, transsexual conflict, professional voice needing urgent phonosurgery and no treated comorbidities (reflux, allergy, thyroid end lung disease).

Using a self-administered questionnaire, the following data were collected: gender, age, height and weight, marital status, educational level, occupation, working experience, exposure to occupational noise and air pollution, additional job, occupational voice demands, family income, physical activity, cigarette smoking, alcohol consumption, comorbidity, symptoms of present voice problems and duration in months and voice problems in the family. Body mass index (BMI) was calculated as weight $(\mathrm{kg})$ divided by height $\left(\mathrm{m}^{2}\right)$. With reference to smoking, each patient was classified as a nonsmoker, former smoker or current smoker. A current smoker was defined as a person who smoked at least one cigarette per day in the 12 months before the disease or who quit smoking within that year. A former smoker was defined as a person who quit for more than a year before the disease occurrence. Regarding alcohol consumption, patients were divided into two groups: ever drinkers and non-drinkers (those who during their life drank less than 12 alcoholic beverages) ${ }^{14}$. Physical activity comprised any kind of unprofessional physical activity for $30 \mathrm{~min}$ per day during the previous month. Persons who exercised more than once a week were considered physically active and the others physically inactive.

For statistical analysis univariate and multivariate logistic regression methods were used. All test variables with statistical significance of $p \leq 0.10$ in the univariate model were included in the multivariate model. Significance was considered with a $\mathrm{p}$ value $<0.05$. Statistical analysis was performed using the SPSS 20 package.

\section{Results}

Of 205 patients with exudative lesions of Reinke's space, $72(35.12 \%)$ were with nodules, $70(34.14 \%)$ with polyps and $63(30.63 \%)$ with oedema.

Characteristics of patients with nodules, polyps and oedema, and differences between these three groups according to univariate logistic regression analysis, are presented in Tables I-III.

When compared with VF polyp patients, those with VF nodules were significantly more frequent in women, younger, not married and with university education. In comparison with VF oedema patients, those with VF nodules were significantly younger, not married, with university education and with high family income. Patients with VF polyps, compared with VF oedema patients, were significantly more frequent in younger men (Table I).

According to data in Table II, patients with VF nodules, compared with VF polyps, significantly differed in occu- 
Table I. Socio-demographic characteristics of patients with vocal fold nodules, polyps and oedema.

\begin{tabular}{|c|c|c|c|c|c|c|}
\hline \multirow[t]{3}{*}{ Variable } & \multicolumn{3}{|c|}{ Patients with } & \multicolumn{3}{|c|}{$p$ value * for } \\
\hline & $\begin{array}{l}\text { VF nodules } \\
(n=72)\end{array}$ & $\begin{array}{l}\text { VF polyps } \\
(\mathrm{n}=70)\end{array}$ & $\begin{array}{l}\text { VF oedema } \\
(\mathrm{n}=63)\end{array}$ & $\begin{array}{l}\text { VF nodules vs } \\
\text { VF polyps }\end{array}$ & $\begin{array}{l}\text { VF nodules vs } \\
\text { VF oedema }\end{array}$ & $\begin{array}{l}\text { VF polyps vs } \\
\text { VF oedema }\end{array}$ \\
\hline & N (\%) & $N(\%)$ & $\mathrm{N}(\%)$ & & & \\
\hline $\begin{array}{l}\text { Gender } \\
\text { Male } \\
\text { Female }\end{array}$ & $\begin{array}{c}3(4.2) \\
69(95.8)\end{array}$ & $\begin{array}{l}37(52.9) \\
33(47.1)\end{array}$ & $\begin{array}{l}7(11.1) \\
56(88.9)\end{array}$ & $<0.001$ & 0.139 & $<0.001$ \\
\hline $\begin{array}{l}\text { Age (years) } \\
\quad \leq 40 \\
\quad>40\end{array}$ & $\begin{array}{l}55(76.4) \\
17(23.6)\end{array}$ & $\begin{array}{l}32(45.7) \\
38(54.3)\end{array}$ & $\begin{array}{c}6(9.5) \\
57(90.5)\end{array}$ & $<0.001$ & $<0.001$ & $<0.001$ \\
\hline Married & $37(51.4)$ & $53(75.7)$ & $46(73.0)$ & 0.003 & 0.011 & 0.722 \\
\hline $\begin{array}{c}\text { Education } \\
\text { Elementary to high school } \\
\text { Faculty }\end{array}$ & $\begin{array}{l}34(47.2) \\
38(52.8)\end{array}$ & $\begin{array}{l}45(64.3) \\
25(35.7)\end{array}$ & $\begin{array}{l}47(74.6) \\
16(25.4)\end{array}$ & 0.042 & 0.010 & 0.200 \\
\hline $\begin{array}{l}\text { Income } \\
\text { Low } \\
\text { Middle } \\
\text { High }\end{array}$ & $\begin{array}{c}1(1.4) \\
38(52.8) \\
33(45.8)\end{array}$ & $\begin{array}{c}2(2.9) \\
45(64.3) \\
23(32.9)\end{array}$ & $\begin{array}{c}3(4.8) \\
41(65.1) \\
19(30.2)\end{array}$ & 0.104 & 0.042 & 0.614 \\
\hline
\end{tabular}

VF: vocal fold; *: according to univariate logistic regression analysis.

pation, had significantly shorter working experience, were significantly more exposed to noise in the working place and more frequently with considerable and immense occupational voice demands.

In comparison with VF oedema patients, VF nodule patients also significantly differed in occupation, had signif- icantly shorter working experience and were significantly more frequent in patients with considerable and immense voice demands.

Patients with polyps and those with VF oedema significantly differed only in the working experience, which was shorter in patients with VF polyps.

Table II. Type of occupation, occupational conditions and professional voice use in patients with vocal fold nodules, polyps and edema.

\begin{tabular}{|c|c|c|c|c|c|c|}
\hline \multirow[t]{3}{*}{ Variable } & \multicolumn{3}{|c|}{ Patients with } & \multicolumn{3}{|c|}{$p$ value * for } \\
\hline & $\begin{array}{l}\text { VF nodules } \\
(n=72)\end{array}$ & $\begin{array}{l}\text { VF polyps } \\
(n=70)\end{array}$ & $\begin{array}{l}\text { VF oedema } \\
(n=63)\end{array}$ & $\begin{array}{l}\text { VF nodules vs } \\
\text { VF polyps }\end{array}$ & $\begin{array}{l}\text { VF nodules vs } \\
\text { VF oedema }\end{array}$ & $\begin{array}{l}\text { VF polyps vs } \\
\text { VF oedema }\end{array}$ \\
\hline & $N(\%)$ & $N(\%)$ & $\mathrm{N}(\%)$ & & & \\
\hline \multicolumn{7}{|l|}{ Type of occupation } \\
\hline Singer, Actor & $9(12.5)$ & $3(4.3)$ & $2(3.2)$ & & & \\
\hline Lecturer & $20(27.8)$ & $4(5.7)$ & $4(6.3)$ & & & \\
\hline Physical worker & $3(4.2)$ & $7(10.0)$ & $11(17.5)$ & & & \\
\hline Administrative worker & $23(31.9)$ & $40(57.1)$ & $23(36.5)$ & 0.003 & 0.044 & 0.238 \\
\hline Health worker & $6(8.3)$ & $5(7.2)$ & $3(4.8)$ & & & \\
\hline Unemployed & $9(12.5)$ & $3(4.3)$ & $1(1.6)$ & & & \\
\hline Retired & $2(2.8)$ & $8(11.4)$ & $19(30.2)$ & & & \\
\hline \multicolumn{7}{|l|}{ Working experience (years) } \\
\hline$<20$ & $51(81.0)$ & 39 (58.2) & $16(25.8)$ & 0.006 & $<0.001$ & $<0.001$ \\
\hline$\geq 20$ & $12(19.0)$ & $28(41.8)$ & $46(74.2)$ & & & \\
\hline Has additional job & $27(37.5)$ & $20(28.4)$ & $19(30.2)$ & 0.259 & 0.370 & 0.841 \\
\hline Noise in the working place & $49(68.1)$ & $35(50.0)$ & $34(54.0)$ & 0.030 & 0.095 & 0648 \\
\hline Polluted air in the working place & $36(50.0)$ & $35(50.0)$ & $30(47.6)$ & 0.782 & 1.000 & 0.784 \\
\hline Occupational voice demands & & & & 0.002 & $<0.001$ & 0.078 \\
\hline No & $18(25.0)$ & $28(40.0)$ & $35(55.5)$ & & & \\
\hline Increased & $17(23.6)$ & $26(37.1)$ & $19(30.2)$ & & & \\
\hline Considerable & $25(34.7)$ & $12(17.1)$ & $7(11.1)$ & & & \\
\hline Immense & $12(16.7)$ & $4(5.7)$ & $2(3.2)$ & & & \\
\hline
\end{tabular}

VF: vocal fold; *: according to univariate logistic regression analysis. 
Table III shows health habits, body mass index, and data from personal and family history of patients with nodules, polyps and oedema.

Patients with VF nodules and those with VF polyps significantly differed only in smoking and BMI. Ever smoking and current smoking were more frequent among patients with VF polyps, who also were more frequently overweight and obese.

According to comparison with VF nodule patients, those with VF oedema were significantly more frequently ever smokers and current smokers, were less frequently physically active and more frequently overweight and obese. They also had hoarseness less frequently as the main presenting symptom and longer duration of symptoms before visiting physician. Altogether other diseases were more frequent among oedema patients, but single disease, allergy, reflux and thyroid diseases were more frequent among VF nodule patients, and cardiovascular diseases among VF oedema patients.

In comparison with VF polyp patients, those with VF oedema were significantly more frequent in ever smok- ers and current smokers, were less frequently physically active, had less frequently hoarseness as the main symptom and had longer duration of symptoms before visiting a physician. Patients with VF oedema significantly more frequently reported family history positive on voice problems.

Variables with statistical significance of $\mathrm{p} \leq 0.10$ according to univariate analysis were included in multivariate analysis. According to multivariate logistic regression analyses (Table IV) there were significant differences between groups for several characteristics. Patients with nodules and oedema were more frequent in women than men in comparison with polyp patients $(\mathrm{p}<0.001)$. Patients with nodules and polyps were younger than oedema patients $(\mathrm{p}<0.001)$. Patients with nodules were more frequently lecturers, singers and actors compared with polyp patients ( $p=0.006)$, had occupational voice demands (considerable and immense) more frequently than patients with oedema $(p=0.037)$ and were less frequently smokers than patients with polyps $(\mathrm{p}=0.043)$ and those with oedema $(\mathrm{p}<0.001)$. Patients with oedema were more frequently

Table III. Smoking, alcohol consumption, recreational physical activity, body mass index, and personal and family history of patients with vocal fold nodules, polyps and oedema.

\begin{tabular}{|c|c|c|c|c|c|c|}
\hline \multirow[t]{3}{*}{ Variable } & \multicolumn{3}{|c|}{ Patients with } & \multicolumn{3}{|c|}{$p$ value * for } \\
\hline & $\begin{array}{l}\text { VF nodules } \\
(\mathrm{n}=72)\end{array}$ & $\begin{array}{c}\text { VF polyps } \\
(n=70)\end{array}$ & $\begin{array}{l}\text { VF oedema } \\
(\mathrm{n}=63)\end{array}$ & $\begin{array}{l}\text { VF nodules vs } \\
\text { VF polyps }\end{array}$ & $\begin{array}{l}\text { VF nodules vs } \\
\text { VF oedema }\end{array}$ & $\begin{array}{l}\text { VF polyps vs } \\
\text { VF oedema }\end{array}$ \\
\hline & N (\%) & $\mathrm{N}(\%)$ & $\mathrm{N}(\%)$ & & & \\
\hline $\begin{array}{l}\text { Smoking status } \\
\text { Non smoker } \\
\text { Former smoker } \\
\text { Current smoker }\end{array}$ & $\begin{array}{l}35(48.6) \\
21(29.2) \\
16(22.2)\end{array}$ & $\begin{array}{l}21(30.0) \\
23(32.9) \\
26(37.1)\end{array}$ & $\begin{array}{c}1(1.6) \\
8(12.7) \\
54(85.7)\end{array}$ & 0.017 & $<0.001$ & 0.002 \\
\hline Alcohol consumption & $18(25.0)$ & 27 (38.6) & $16(25.4)$ & 0.084 & 0.958 & 0.107 \\
\hline Physically active (recreation) & $56(77.8)$ & $50(71.4)$ & $32(50.8)$ & 0.386 & 0.001 & 0.015 \\
\hline $\begin{array}{l}\text { Body mass index } \\
\text { Normal weight } \\
\text { Overweight or obese }\end{array}$ & $\begin{array}{l}56(77.8) \\
16(22.2)\end{array}$ & $\begin{array}{l}35(50.0) \\
35(50.0)\end{array}$ & $\begin{array}{l}27(42.9) \\
36(57.1)\end{array}$ & 0.001 & $<0.001$ & 0.847 \\
\hline $\begin{array}{c}\text { Present disease symptoms } \\
\text { Hoarseness } \\
\text { Dyspnea } \\
\text { Other }\end{array}$ & $\begin{array}{c}62(86.1) \\
1(1.4) \\
9(12.5)\end{array}$ & $\begin{array}{c}55(78.6) \\
1(1.4) \\
14(20.0)\end{array}$ & $\begin{array}{c}38(60.3) \\
3(4.8) \\
22(34.9)\end{array}$ & 0.229 & 0.001 & 0.033 \\
\hline $\begin{array}{l}\text { Duration of symptoms (months) } \\
\qquad \begin{array}{l}\leq 12 \\
>12\end{array}\end{array}$ & $\begin{array}{c}60(83.30) \\
12(16.7)\end{array}$ & $\begin{array}{l}50(71.4) \\
20(28.6)\end{array}$ & $\begin{array}{l}29(46.0) \\
34(54.0)\end{array}$ & 0.093 & $<0.001$ & 0.003 \\
\hline Has some other diseases & $36(50.0)$ & $41(58.6)$ & $45(71.9)$ & 0.306 & 0.012 & 0.123 \\
\hline $\begin{array}{c}\text { Type of other disease } \\
\text { Allergy } \\
\text { Reflux } \\
\text { Thyroid } \\
\text { Cardiovascular } \\
\text { Other }\end{array}$ & $\begin{array}{l}7(19.4) \\
10(27.8) \\
7(19.4) \\
5(13.9) \\
7(19.4)\end{array}$ & $\begin{array}{c}5(12.2) \\
12(29.3) \\
7(17.1) \\
7(17.1) \\
10(24.4)\end{array}$ & $\begin{array}{c}3(6.7) \\
6(13.3) \\
8(17.6) \\
17(37.8) \\
11(24.4)\end{array}$ & 0.414 & 0.016 & 0.093 \\
\hline Voice problems in the family & $11(15.3)$ & $8(11.4)$ & $18(28.6)$ & 0.502 & 0.064 & 0.016 \\
\hline
\end{tabular}

VF: vocal fold; *: according to univariate logistic regression analysis. 
Table IV. Characteristics which significantly differed between patients with vocal fold nodules, polyps and oedema, according to multivariate logistic regression analysis.

\begin{tabular}{|c|c|c|c|c|c|c|}
\hline \multirow[t]{2}{*}{ Variable } & \multicolumn{2}{|c|}{$\begin{array}{l}\text { VF nodule patients vs } \\
\text { VF polyp patients }\end{array}$} & \multicolumn{2}{|c|}{$\begin{array}{l}\text { VF nodule patients vs } \\
\text { VF oedema patients }\end{array}$} & \multicolumn{2}{|c|}{$\begin{array}{l}\text { VF polyp patients vs } \\
\text { VF oedema patients }\end{array}$} \\
\hline & OR (95\% Cl) & $p$ value & OR (95\% Cl) & $p$ value & OR (95\% Cl) & $p$ value \\
\hline Gender (women/ men) & $\begin{array}{c}30.30 \\
(8.13-111.11)\end{array}$ & $p<0.001$ & & & $\begin{array}{c}0.07 \\
(0.02-0.24)\end{array}$ & $<0.001$ \\
\hline Age ( $\leq 40$ years $/>40$ years $)$ & & & $\begin{array}{c}14.03 \\
(3.58-54.92)\end{array}$ & $p<0.001$ & $\begin{array}{c}17.27 \\
(4.36-68.36)\end{array}$ & $<0.001$ \\
\hline Occupation * & $\begin{array}{c}2.50 \\
(1.30-4.76)\end{array}$ & 0.006 & & & & \\
\hline Occupational voice demands ${ }^{\dagger}$ & & & $\begin{array}{c}2.04 \\
(1.04-4.0)\end{array}$ & 0.037 & & \\
\hline Smoker (no; former; current) & $\begin{array}{c}0.59 \\
(90.35-0.98)\end{array}$ & 0.043 & $\begin{array}{c}0.15 \\
(0.06-0.37)\end{array}$ & $<0.001$ & $\begin{array}{c}0.19 \\
(0.08-0.43)\end{array}$ & $<0.001$ \\
\hline $\begin{array}{l}\text { Symptoms of the present disease } \\
\text { (hoarseness/dyspnoea and others) }\end{array}$ & $\begin{array}{c}2.93 \\
(1.05-8.20)\end{array}$ & 0.040 & $\begin{array}{c}13.49 \\
(2.75-66.15)\end{array}$ & 0.001 & & \\
\hline Voice problems in the family (yes/no) & & & & & $\begin{array}{c}0.13 \\
(0.03-0.53)\end{array}$ & 0.005 \\
\hline
\end{tabular}

VF: vocal fold; OR: odds ratio; Cl: confidence intervals.

*: unemployed or retired; physical, administrative or health worker; singer, actor, lecturer.

t: no; increased; considerable; immense.

current smokers than patients with nodules and those with polyps $(\mathrm{p}<0.001)$. Hoarseness as the main symptom of the present disease was more frequent among patients with nodules than among patients with polyps $(\mathrm{p}=0.040)$ and those with oedema $(p=0.001)$. Voice problems in the family were more frequently reported by oedema patients than by those with polyps $(\mathrm{p}=0.005)$.

\section{Discussion}

It is still a paradigm how to classify vocal fold nodules, polyps and edema ${ }^{15}$. Although it seems reasonable to place all of the three together, there are some differences between them. In the present study, patients with nodules, polyps and oedema significantly differed in seven characteristics: gender, age, occupation, occupational voice demands, smoking, family history of voice problems and symptoms.

Age and gender related risks for specific voice disorders have been highlighted by other authors ${ }^{16}{ }^{17}$. In our investigation, the three groups were strictly divided. VF nodule patients were predominantly at the age of 40 and under, and VF oedema patients at the age of 41 and over. The VF polyps group was more balanced, with 32 patients with an age of 40 and under, and 38 patients with an age of 41 and over. In the investigation by Yoon Se Lee et al. ${ }^{18}$ the age range for vocal fold polyps in the group of 41 males and 51 females was 22-72 years, with an average of 51 .
The reasons for this age distribution are still not clear, but from a socio-demographic point of view it seems that VF nodules are a disease of the young, and that VF oedema is a disease of an older population because of large differences in vocal and health behaviour of these two groups. In our investigation, in the VF polyps group $52.9 \%$ of patients were men, compared to only $4.2 \%$ in the VF nodules group and $11.1 \%$ in the VF oedema group. This gender difference may be related to many factors, both genetic and psychological, but also with environmental factors ${ }^{3}$. It would seem that gender and age are of importance in determination in which direction one exudative lesion of Reinke's space will develop. Women with vocal folds in the presence of risk factors will develop nodules rather than polyps. Older women with vocal folds in the presence of risk factors will develop oedema rather than polyps. The reasons for this are still unclear, probably lying at the molecular level, and likely associated with contributing factors such as occupational voice demands, smoking and delay of seeking medicine attention.

The type of occupation has also been recognised as a risk factor for VF disease ${ }^{8}$. In fact, the type of occupation is related to voice demands and air pollution. The incidence of vocal fold nodules and polyps correlates with vocal overuse ${ }^{19}$. Increased vocal use, predominantly linked to the VF polyps group, was connected with professions such as army and police commanders, street and other sale persons, receptionists, medical stuff and speech and 
language therapists, lawyers, judges, hair dressers. Considerable vocal use, mostly linked to VF nodules group, was registered in teaching stuff, telephone operators, clerks, politicians, sport trainer and managers. For example, in a study from Spain, the prevalence of voice disorders among teachers was $14 \%$ for nodular lesions, $2 \%$ for polyps and $1.2 \%$ for Reinke's oedema ${ }^{20}$. In the study conduted by Krecicki et al. ${ }^{8}$, women formed the majority, and teachers formed the largest occupational group (30\%). Immense vocal use, also linked to the VF nodules group, is present in singers, actors, TV and radio speakers and showmen ${ }^{19}$. In our investigation, VF nodules were linked to voice overuse (considerable and immense occupational voice demands). Alvarez also found that voice abuse or misuse was the main factor in patients with VF nodules ${ }^{21}$.

There is general acceptance of a close relationship between chronic cigarette smoke exposure and onset of voice pathology, especially Reinke's oedema ${ }^{7}$. In the study by Krecicki et al. ${ }^{8}$ most VF oedema patients (86\%) were smokers. According to the investigation by Alvarez et al. ${ }^{21}$ smoking was the main symptom in polyps and oedema. In our study, smokers were most frequent among VF oedema patients. Up to $98.4 \%$ of patients with oedema were ever smokers, and $85.7 \%$ were current smokers. Among patients with VF polyps, $70.0 \%$ were smokers (37.1\% current smokers), which was less than among patients with oedema but more than among those with nodules. However, there are few basic investigations on this subject, and the existing studies do not give firm evidence about the effects of smoking on formation of vocal fold oedema ${ }^{22} 23$.

In the present study, family history positive for vocal problems was reported by $11.4 \%$ to $28.6 \%$ patients, and was most frequent in oedema patients. It has been considered that genetic factors play role in the development of VF nodules, polyps and oedema ${ }^{34}$. There is a possibility that various genes are associated with each of VF disorders - nodules, polyps, edema - and that their expression is influenced by various environmental factors. However, there is also possibility of recall differences between compared groups.

In patients with VF oedema, symptoms other than hoarseness were more frequent (39.7\%) than in the other two groups of patients. This can be explained since in a large number of patients with oedema, symptoms lasted more than 12 months before they visited a physician.

In summary, on the basis of mutual comparisons of patients with VF nodules, polyps and oedema, the main characteristics of these three types of vocal fold were as follows: patients with nodules were most frequently women $\leq 40$ years old, with a high-risk occupation (lecturer, singer, actor), with considerable and intensive occupational voice demands, with a similar proportion of ever smokers and non-smokers, and hoarseness as a dominant symptom; patients with polyps were almost equally distributed by gender and age, were most frequently administrative workers, frequently ever smokers and current smokers and had hoarseness as a dominant symptom; patients with oedema were most frequently women 41 or more years old, without or with slightly increased occupational voice demands, almost all were ever smokers and large proportion were current smokers, more than a quarter of them had positive family history on voice problems, and a considerable number had symptoms other than hoarseness.

Besides limitations related to collection of data by the use of the questionnaire, the main limitation is the relatively small number of patients.

\section{Conclusions}

Mutual comparisons of patients with VF nodules, polyps and oedema showed that they differed in several main characteristics. These findings are in agreement with the majority of existing studies and may be of help in future investigations on the aetiology of the disease.

\section{Conflict of interest statement}

None declared.

\section{References}

1 Friedrich G, Remacle M, Birchall M, et al. Defining phonosurgery: a proposal for classification and nomenclature by the phonosurgery committee of the European laryngological Society (ELS). Eur Arch Otorhinolaryngol 2007;264:1191-200.

2 Hantzakos A, Remacle M, Dikkers FG, et al. Exudative lesions of Reinke's space: a terminology proposal. Eur Arch Otorhinolaryngol 2009;266:869-78.

3 Gray SD, Thibeault SL. Diversity in voice characteristicsinteraction between genes and environment, use of microarray analysis. J Commun Disord 2002;35:347-54.

4 Van Lierde KM, Vinck B, De Ley S, et al. Genetics of vocal quality characteristics in monozygotic twins: a multiparameter approach. J Voice 2005; 19:511-8.

5 Salmen T, Ermakova T, Schindler A et al. Efficacy of microsurgery in Reinke's oedema evaluated by traditional voice assessment integrated with the Vocal Extent Measure (VEM). Acta Otorhinolaryngol Ital 2018;38:194-203.

6 Roy N, Kim J, Courey M. et al. Voice disorders in the elderly: A national database study. Laryngoscope 2016;126:421-8. 
7 Marcotullio D, Magliulo G, Pezone T. Reinke's edema and risk factors: clinical and histopathologic aspects. Am J Otolaryngol 2002;23:81-4.

8 Krecicki T, Zalesska-Krecicka M, Pastuszek P, et al. Treatment of Reincke's edema among different professional groups: presentation of results. Int J Occup Med Environ Health 2004; 17:279-84.

9 Kravos A, Zupevc A, Cizmarevic B, et al. The role of allergy in the etiology of Reinke's edema on vocal folds. Wien KlinWochenschr 2010;122(Suppl 2):44-8.

10 Tiba M, Fawaz S, Osman H. Helicobacter pylori and its role in vocal folds'minimal lesions. Clin Respir J 2010;4:237-40.

11 Kim KH, Kim RB, Hwang DU, et al. Prevalence of and sociodemographic factors related to voice disorders in South Korea. J Voice 2016;30:246.e1-7.

12 Roy N, Merril MR, Gray SD, et al. Voice disorders in the general population: prevalence, risk factors, and occupational impact. Laryngoscope 2005;115:1988-95.

13 Naunheim MR, Carroll TL. Benign vocal fold lesions: update on nomenclature, cause, diagnosis, and treatment. Curr Opin Otolaryngol Head Neck Surg 2017;25:453-8.

14 Freiberg MS, Cabral HJ, Heeren TC, et al. Alcohol consumption and the prevalence of the metabolic syndrome in the U.S. A cross-sectional analysis of data from the Third National Health and Nutrition Examination Survey. Diabetes Care 2004;27:2954-9.

15 Rosen CA, Gartner-Schmidt J, Hathaway B, et al. A nomenclature paradigm for benign midmembranous vocal fold lesions. Laryngoscope 2012;122:1335-41.
16 De Bodt M, Van den Steen L, Mertens F, et al. Characteristics of a dysphonic population referred for voice assessment and/or voice therapy. Folia Phoniatr Logop 2015;67:178-86.

17 Zhukhovitskaya A, Battaglia D, Khosla SM, et al. Gender and age in benign vocal fold lesions. Laryngoscope 2015;125:191-6.

18 Lee YS, Lee DH, Jeong GE, et al. Treatment efficacy of voice therapy for vocal fold polyps and factors predictive of its efficacy. J Voice 2017;31:120.e9-13.

19 Bastian RW, Thomas JP. Do talkativeness and vocal loudness correlate with laryngeal pathology? A study of the vocal overdoer/underdoer continuum. J Voice 2016;30:557-62.

20 Preciado J, PerezC, Calzada M, et al. Prevalence and incidence studies of voice disorders among teaching staff of La Rioja, Spain. Clinical study: questionnaire, function vocal examination, acoustic analysis and videolaryngostroboscopy. Acta Otorrinolaringol Esp 2005;56:202-10.

21 García Alvarez CD, Campos Bañales ME, López Campos D, et al. Polyps, nodules, and Reinke edema. An epidemiological and histopathological study. Acta Otorrinolaringol Esp 1999;50:443-7.

22 Branski RC, Zhou H, Kraus DH, et al. The effects of cigarette smoke condensate on vocal fold transepithelial resistance and inflammatory signaling in vocal fold fibroblasts. Laryngoscope 2011;121:601-5.

23 Effat KG, Milad M. A comparative histopathological study of vocal fold polyps in smokers versus nonsmokers. J Laryngol Otol 2015;129:484-8. 